\title{
Determining mycorrhiza rate in some oak species inoculated with $T u b e r$ aestivum Vittad. (summer truffle)
}

\author{
Sevgin Özderin ${ }^{\mathrm{a}, *}$, Ferah Yılmaz $^{\mathrm{b}}$, Hakan Allı
}

\begin{abstract}
Truffle cultivation is important because it has contributions to tourism as well as other sectors and is a significant activity especially in stimulating rural economy. In this article, it is aimed to determine the most suitable oak species for the development of the Tuber aestivum Vittad. (summer truffle) and to provide guidance for the establishment of truffle gardens. Quercus robur L., $Q$. ilex L., $Q$. coccifera $\mathrm{L}$ were germinated, the seedlings were inoculated with $T$. aestivum which is an important element of Turkish biological diversity. The mycorrhiza were counted in the roots after the 15-month growth period of the seedlings to which T. aestivum was inoculated. As a result of the counts, it was determined that the rate of the roots with mycorrhiza (PT) was 0.93 in $Q$. robur L., 0.91 in $Q$. coccifera L. and 0.90 in Q. ilex L. Contaminated root rate (PC) was 0.28 in Q. robur $\mathrm{L}$., 0.28 in $Q$. ilex $\mathrm{L}$. and 0.30 in $Q$. coccifera $\mathrm{L}$. According to the results, $Q$. robur is the oak species with the highest mycorrhizal development rate.

Keywords: Tuber aestivum, Truffle, Oak, Muğla, Turkey
\end{abstract}

\section{Tuber aestivum Vittad. (yazlık trüf) aşılanmış bazı Quercus fidanlarında mikoriza oranlarının belirlenmesi}

\begin{abstract}
Özet: Trüf yetiştiriciliği, özellikle kırsal ekonomiyi canlandırmakta önemli bir faaliyet olmasının yanı sıra, turizm ve diğer sektörlere olan katkısından dolayı oldukça önemlidir. Bu çalışmada, Tuber aestivum Vittad. (yaz trüfü) gelişimi için en uygun meşe türünün belirlenmesi ve trüf bahçesi kurulumu için rehber olmak amaçlanmıştır. Çalışmada Quercus robur L., $Q$. ilex L., Q. coccifera $\mathrm{L}$. türlerinin tohumları çimlendirilip, elde edilen fidanlar biyolojik çeşitliliğimizin önemli bir parçası olan trüf mantarı türlerinden T. aestivum ile aşılanmıştır. Aşılanmış fidanların 15 aylık gelişim süreci sonunda köklerdeki mikoriza sayımları yapılmıştır. Yapılan sayımlar sonucunda mikorizalı kök oranı (PT) $Q$. robur L. da 0,$93 ;$ Q coccifera L. da 0,$91 ; Q$. ilex L. de 0,90 bulunmuştur. Kontamine kök oran $(\mathrm{PC})$ ise $Q$. robur $\mathrm{L}$. da 0,$28 ;$ Q ilex $\mathrm{L}$. de 0,$29 ;$ Q coccifera $\mathrm{L}$. da ise 0,30 olarak tespit edilmiştir. Bu sonuçlara göre mikorizal gelişimin en yüksek olduğu meşe türü $Q$. robur'dur.

Anahtar kelimeler: Tuber aestivum, Trüf, Meșe, Muğla, Türkiye
\end{abstract}

\section{Introduction}

Truffle species grow underground and belong to the Tuber species of the Ascomycetes class, Tuberales ordo Tuberaceae family (Bonito et al., 2009). Unlike many ground surface fungi, truffle species is a mycorrhizal fungus that has potato-like structures under the ground (Trappe et al., 2009). While mycorrhizal fungi take the products obtained as a result of photosynthesis from the plant, they form mycorrhiza and supplly the water and inorganic substances needed by the plants (Serrada, 2008).

Ectomycorrhizal fungi are found in approximately $10 \%$ of the world's flora, mainly on Fagaceae (oak, chestnut, beech), Pinaceae (pine, fir, black pine, spruce tree), Juglandaceae (American walnut, pican walnut), Betulaceae (alder, birch) Salicaceae (poplar, willow), Myrtaceae (eucalyptus) and they form mutual life forms with some other trees (Marx, 2001). In areas where T. aestivum is common in temperate climate areas, mostly Quercus robur L., Q. cerris L., Corylus avellana L., Fagus sylvatica L.
Tilia cordata Miller, Pinus brutia Ten., P. halepensis Mill., P. nigra L. are common (Stobbe et al., 2013; Wedén et al., 2004; Hall et al., 2007).

Although it is estimated that there are 180-230 cultivars of truffle around the world, approximately 13 of them are commercially used, which includes Tuber aestivum Vittad., T. melanosporum Vittad., T. magnatum Picco (Serrada, 2008, Bonito et al., 2010). T. aestivum was first defined by Carlo Vittadini in 1831 (Vittadini, 1831) and it was reported that it had black peridium and brown gleba (Montecchi and Sarasini, 2000; Callot, 1999; Chevalier and Frochot, 2002). T. aestivum naturally spreads in all over Europe in Sweden (Wedén et al., 2004; Song et al., 2005; Chevalier and Frochot, 1997a; Montecchi and Sarasini, 2000), Poland (Ceruti et al., 2003), France, Italy (Zambonelli et al., 2002), England (Wedén and Danell, 1998), Germany, Switzerland (Stobbe et al., 2012), Denmark (Lange, 1994), Czechoslovakia (Gryndler et al., 2011), Ukraine (Arredondo-Ruiz et al., 2014), Spain, Holland, Turkey (Stielow and Menzel, 2010; Jeandroz et al., 2008), Portugal

\footnotetext{
$\bowtie$ a Muğla Sıtkı Koçman University, Truffle Application and Research Center, Muğla, Turkey

Muğla Sıtkı Koçman University, Faculty of Agriculture, Muğla, Turkey

Muğla S1tkı Koçman University, Faculty of Science, Muğla, Turkey

@ * Corresponding author (İletişim yazarı): sevginozderin@ mu.edu.tr

$\checkmark \quad$ Received (Geliş tarihi): 21.06.2018, Accepted (Kabul tarihi): 29.09.2018
}

Citation (Atıf): Özderin, S., Yılmaz, F., Allı, H. 2018. Determining mycorrhiza rate in some oak species inoculated with Tuber aestivum Vittad. (summer truffle). Turkish Journal of Forestry, 19(3): 226-232. DOI: $10.18182 /$ tjf.435372 
(Stobbe et al., 2012; Stobbe et al., 2013) and in North Africa (Wedén and Danell, 1998, Jeandroz et al., 2008; Ceruti et al., 2003; Song et al., 2005), in Algeria (Stielow and Menzel, 2010), Israel (Turgeman et al., 2012), Azerbaijan (Fekete et al., 2014; Chevalier and Frochot, 1997a, Wedén and Danell, 1998, Ceruti et al., 2003), China (Ceruti et al., 2003, Arredondo-Ruiz et al., 2014), New Zealand and the USA (Zambonelli et al., 2002).

Turkey is located as a bridge of the European and Asian flora and in the Mediterranean belt where the countries have rich truffle biodiversity and it shows high biodiversity of ectomycorrhizal fungi such as truffles. The studies conducted on truffle species in Turkey are limited in number and are inadequate because truffle fungi is subject to less interest than the ground surface fungi. Although $T$. aestivum cosmopolite is an edible truffle, studies on its ecological and geographical distribution have not been completed yet (Montecchi and Sarasini, 2000; ArredondoRuiz et al., 2014). Twenty-three genus and 15 families belonging to 67 truffle taxa have been determined in Turkey so far (Oder, 1988; Isiloglu and Oder 1995; Afyon, 1996; Doğan and Öztürk, 2006; Solak et al., 2007; Kaya, 2009; Castellano and Turkoglu, 2012; Turkoglu and Castellano, 2014; Turkoglu et al., 2015; Sen et al., 2016). T. aestivum is one of these and spreads in Antalya, Artvin, Bolu, Burdur, Denizli, Düzce, Hatay, Istanbul, Izmir, Muğla, Kırklareli, Ordu, Osmaniye in Turkey (Sen et al., 2016, Figure 1).

Truffle prices, which reached the highest values in the $19^{\text {th }}$ century, has reduced the total amount of truffle in natural habitats despite the continuous development of the truffle market. As a result of this situation the need for the establishment of truffle gardens emerged (Olivier, 2000; Hall et al., 2001 and 2003). Truffle cultivation is made in Italy, France, and Spain because the amount in natural environment decreased and this brings low input and high income to the cultivators in economic terms. Between the years 1970-1990, the truffle trade in the world was dominated by three countries (France, Italy, Spain); and as of 1990s, New Zealand, Australia and the USA started to emerge in this market (Morcillo et al., 2007). Although truffle harvest was made in the gardens in 5-7 years, it was also reported that the first truffle emerged within 3-4 years in some optimum conditions (Sourzat, 2001; Lefevre et al., 2001; Chevalier and Frochot, 2002; Streiblová et al., 2010). Today, more than half of the truffle amount obtained worldwide are harvested from truffle gardens (Mello et al., 2006). In Italy, $50 \mathrm{~kg} / \mathrm{ha}$ truffle is harvested on an annual scale from the 13-14-year-old truffle gardens (Bencivenga and Di Massimo, 2000); in Spain, $45 \mathrm{~kg} / \mathrm{ha}$ truffle was harvested from 13-14-year-old gardens (Carbajo, 2000); in France, $15-50 \mathrm{~kg} / \mathrm{ha}$ and rarely $110 \mathrm{~kg} / \mathrm{ha}$ truffle is harvested from 14-year-old gardens (Chevalier and Frochot, 1997b). Resently the prices of truffle have risen up to $€ 700-900$ because of the decreased production due to summer drought in Europe where it was between 300-450 euro $/ \mathrm{kg}$. Truffle hunters in Gotland sell T. aestivum truffles at a price of $€ 350-500$ per $\mathrm{kg}$. Thus, while $€ 3500$ is earned from $10 \mathrm{~kg}$ truffle harvest per hectare, this increases up to $€ 14,000$ with $40 \mathrm{~kg} / \mathrm{ha}$ harvest (Bonet et al., 2009).

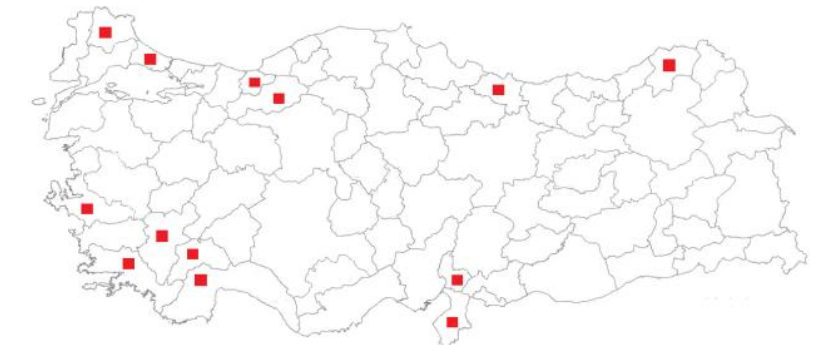

Figure 1. The distribution of T. aestivum Vittad in Turkey (Sen et al., 2016)

The consumption of truffle fungi as food ensures that truffle collectors and cultivators gain income, and truffle festivals are organized to bring tourism income by ensuring the participation of local and foreign tourists. In addition, as a result of the increase in truffle cultivation, these positive contributions are also provided; the economic value of fields and lands that can be cultivated increases and increase in sales of materials such as tools and equipment used during the establishment of truffle gardens contribute to the country's economy. For example, in France, $T$. melanosporum has an effect of 70 million Euros to the economy of the country (Escafre and Roussel, 2006); and in Spain, this amount is 7.5 million Euros; in Australia, it is 4 million Euros (Duell, 2012.), and in Italy, the income brought by Tuber genus is more than 100 million Euros (Gregori, 2013).

The decrease in the amount of truffle fungus in natural environments day by day leads to an increase in demand. With this study, it is aimed to shed light on both truffle hunters and investors who want to establish truffle gardens and contribute to the national economy by investing in this field. For this reason, T. aestivum Vittad. inoculation was made to 3 different oak trees that grow naturally in many areas of Turkey; and the mycorrhizal developments were examined in the seedlings. In this article, it is aimed to determine the most suitable oak species for the development of the Tuber aestivum and to provide guidance for the establishment of truffle gardens.

\section{Material and method}

\subsection{Collection of the seeds and truffles}

In this study, the seeds of common oak (Quercus robur L.), holm oak (Q. ilex L. ), kermes oak (Q. coccifera L.), were collected in ripening periods (October-November, 2017). Q. robur seeds were collected from the Pamukkale University campus at $450 \mathrm{~m}$ elevation, $Q$. ilex $\mathrm{L}$. seeds from the Dilek at $67 \mathrm{~m}$ elevation and $Q$. coccifera $\mathrm{L}$. seeds from Çiçekli at $328 \mathrm{~m}$ elavation. The seeds were kept in plastic containers in perlite at $\pm 4{ }^{\circ} \mathrm{C}$ for 2 months until the inoculation study at the Truffle Application and Research Center of the Muğla Sitkı Koçman University.

The $T$. aestivum Vittad. ascocarps were collected at different localities in Denizli, Aydın and Muğla in spring and early summer as ripe ascocarps from Pinus brutia (Ten.) and various Quercus forests, their localities and habitats were defined and photographed (Hall et all., 2007). The soil remains on the ascocarps were cleaned with a brush and water, and the ascocarps that had rotten parts or larvae were removed from the experiment. Samples were taken 
from each ascocarp, macroscopic and microscopic examinations were made, and the ascocarps that were suitable for spore isolation were seperated. The selected ascocarps were sterilized with $75 \%$ alcohol (Yuanzhi, 2016), were put in plastic bags and kept at $-20{ }^{\circ} \mathrm{C}$ (Giorgio et al. 2016; Yuanzhi, 2016) until the inoculation experiments were initiated.

\subsection{Seed Germination}

A total of 1200 seeds (400 for each species) were used for the germination. The oak seeds were kept at warm distilled water for 10 days to swell and then they were sterilized in $5 \%$ hydrochloric acid in plastic containers. Then, perlite was sterilized in a sterilizer at $121{ }^{\circ} \mathrm{C}$ at 1.5 atm pressure for 1 hour. Seeds were left to develop in perlite at $20{ }^{\circ} \mathrm{C}$, in 16 -hour light cycles and at 50-60\% humidity for 100 days. The germination rates were determined by counting at $15,30,45$ and $100^{\text {th }}$ days after germination. The plants that were suitable for truffle inoculation (Fischer and Colinas, 1996; Council Directive 1999/105/EC of 22 December, 1999) were selected and the others were discarded from the experiment (Figure 2).

\subsection{Sterilization of the air pots}

Plastic pots $\left(1.9 \mathrm{dm}^{3}\right)$ were used for transplantation of the plants in the trial, after they were washed with tap water and kept at $10 \% \mathrm{HCl}$ solution for 24 hours before the trial, and then were washed again with distilled water.

\subsection{Inoculation}

In March 2017, a $720 \mathrm{~g}$ sample of the healthy ascocarps was weighed and blended in $2 \mathrm{~L}$ distilled water. Then, agarose/water mixture (7 g Sigma agarose / $1 \mathrm{~L}$ ) was added and mixed again to obtain a homogenous solution. Roots of the randomly selected seedlings were submerged in the solution to ensure inoculation (Fischer and Colinas, 1996). The inoculated seedlings were planted into the plastic pots with $2 \mathrm{~L}$ sterilized torf. For each oak species, 180 seedlings were inoculated with the truffle and they were left to grow for 15 months at \% 50 humidity, 12 hour daylight and 25-35 ${ }^{\circ} \mathrm{C}$ temperature, by applying regular care in groups of 60 seedlings (Zambonelli et al.,1993, Figure 3).

\subsection{Determining the mycorrhiza rates and identification of the ectomycorrhiza}

After the 15-month growth period, 12 seedlings were randomly selected as 4 from each oak species and brought to the laboratory. After these seedlings were removed from the pots with care, the roots were first washed with distilled water to remove the soil layer. Then $2 \mathrm{~cm}$ pieces were cut from the roots (Fischer and Colinas, 1996; Reyna et al., 2000) and placed in petri dishes with distilled water (Avis et al., 2003). Afterwards, mycorrhizal and contaminated (Agerer, 1991) root pieces were counted anatomically and morphologically (Zambonelli et al., 1993) under the stereo microscope (Olympus SZX7). A total of 250 root parts were examined from each plant species in the counting process. The mycorrhization rates were computed are as follows;
$\mathrm{PT}=\mathrm{T} /(\mathrm{N}+\mathrm{C})$

$\mathrm{PC}=\mathrm{C} / \mathrm{T}$

Where;

PT: T. aestivum mycorrhiza rate

PC: Contamination rate

T: T. aestivum mycorrhiza root part count

$\mathrm{N}$ : Non-mycorrhiza root part count

C: Contaminated root part count
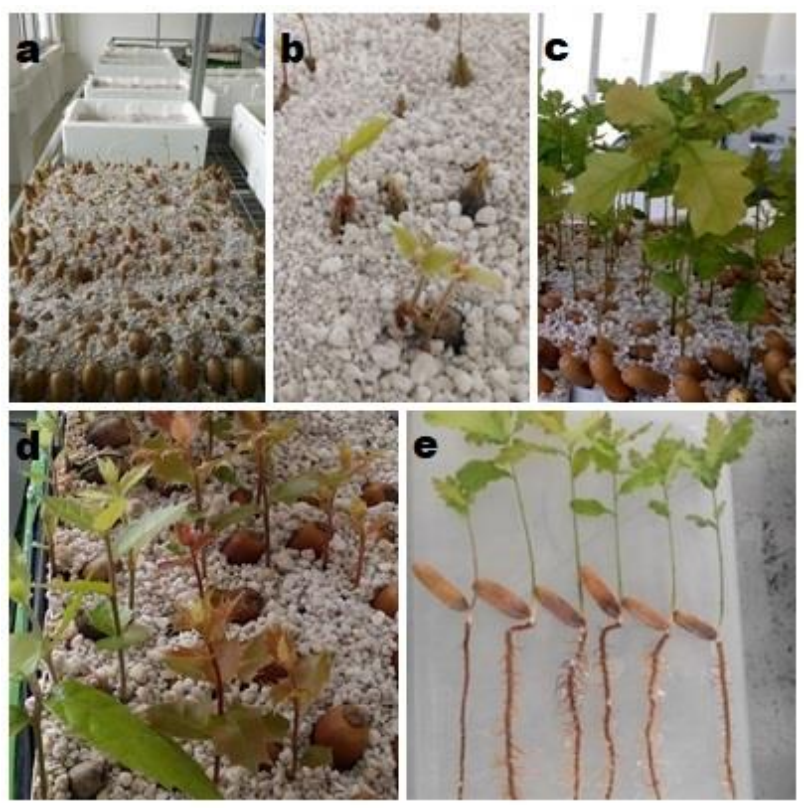

Figure 2. Germination of the seeds in perlite (a), Q. ilex germination (b), $Q$. robur germination (c), $Q$. ilex and $Q$. coccifera germination (d), Q. robur seedlings (e)

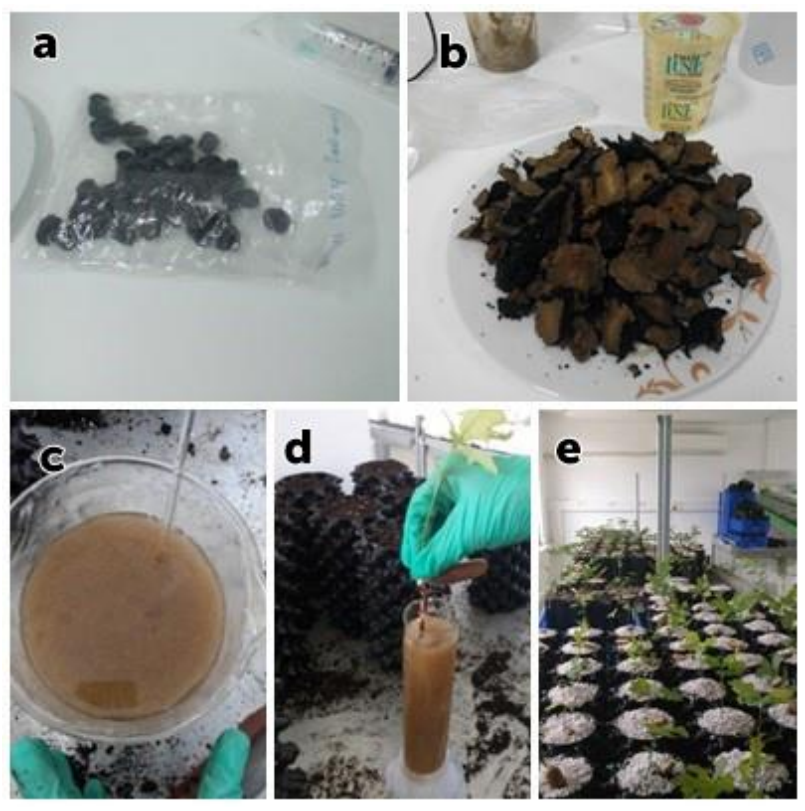

Figure 3. Tuber aestivum Vittad. ascocarps (a), the ascocarps grinded with blender (b), the solution to be used for the inoculation (c), the inoculating process (d), the inoculated oak seedlings left to grow (e) 
After the crust layer on the mycorrhizal structures was taken as sections with a razor blade (Agerer, 1991), it was placed on the slide and photographed (Leica 40X) with the help of $15 \% \mathrm{KOH}$ solution

\section{Results}

\subsection{Germination percentages}

In the present study, 904 seeds germinated from the total of 1200 seeds. It was determined that 360 of the 400 pcs of Q. ilex L. germinated (90\%); 248 of the 400 pcs of $Q$. robur L. germinated (62\%) and 234 of the 400 pcs of Q. coccifera L. germinated (59\%) among these seeds that were placed in the germination container (Figure 4).

\subsection{Determining the mycorrhiza rates}

Mycorhizal counts showed that the PT rates for $Q$. robur L. seedlings were between 0.66 and 1.34; the PC rates were between 0.24 and 0.31 , resulting in a mean PT rate of 0.93 and a mean PC rate of 0.28 (Figure 5). Similarly, the PT rates for $Q$. ilex $\mathrm{L}$. seedlings were between 0.70 and 1.03 , the PC rates were between 0.24 and 0.32 , resulting in a mean PT rate of 0.90 and the PC rate of 0.29 . For the $Q$. coccifera L. seedlings, the PT rates were between 0.58 and 1.14 , the PC rates were between 0.23 and 0.33 , with the mean PT rate of 0.91 and the mean $\mathrm{PC}$ rate of 0.30 .

\section{Discussion and conclusions}

The definition of ectomycorrhizal root types is possible with the color, size, branching type and the existence of the crust layer and cystidia (Granetti, 1995). This must be known for not only scientific studies but also for establishing truffle gardens (Gardes and Bruns, 1996; Zeppa et al., 2005). Although the Tuber genus show variations in terms of their economic value and ecological demands, their mycorrhizal structures may show interesting similarities in a striking manner. For this reason, although Tuber mycorrhizas may be detected as species, the distinction of them may be difficult in terms of mycorrhizal structures at genus level (Kovacs and Jakucs, 2006).

In $T$. aestivum, mycorrhizas show a wool-like surface that is formed with the curving and "weaving" of many cystidia. Unlike the vegetative hypha, cystidia never shows branching, and may have septa-free and vesical (Zambonelli et al., 1993; Müller et al., 1996, Figures 6 and 7). The edges of the cystidia are in the shape of a knop with irregular shapes. Mycorrhiza have yellowish brown and okra color in the periods when cystidia grow anew in early periods. As the mycorrhiza ripen, they become dark brown in color and may start to lose their cystidia. Their cornered cells in the internal and external layers of the crust layer are pseudoparenchymatic and do not have rhizomorph.

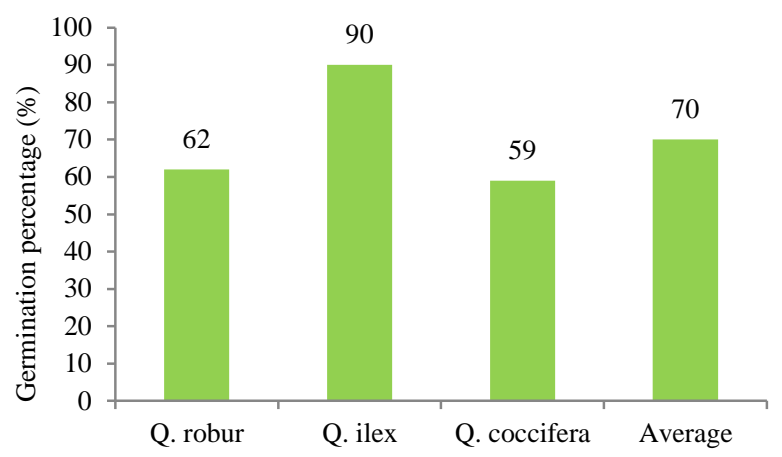

Figure 4 . The germination percentage of the oak seeds (\%)

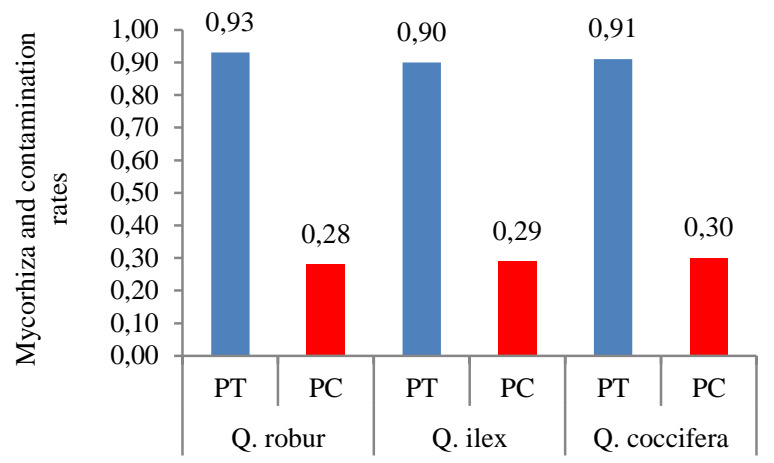

Figure 5. Mean mycorrhiza $(\mathrm{PT}=\mathrm{T} /(\mathrm{N}+\mathrm{C})$ and contamination $(\mathrm{PC}=\mathrm{C} / \mathrm{T})$ rates for $Q$. robur, $Q$. ilex and $Q$. coccifera seedlings
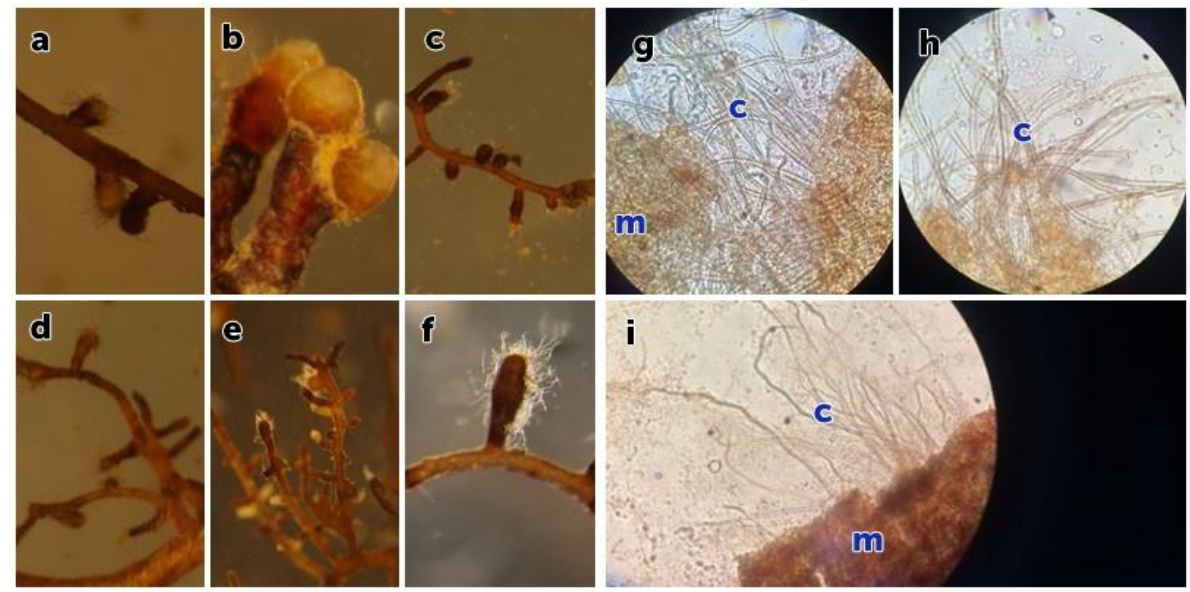

Figure 6. The mycorrhizal structure in the roots $(\mathrm{a}, \mathrm{b}, \mathrm{c}, \mathrm{d}, \mathrm{e}, \mathrm{f})$, the mantle $[\mathrm{m}]$ sheath and the cystidia $[\mathrm{c}](\mathrm{g}, \mathrm{h}, \mathrm{i})$ 


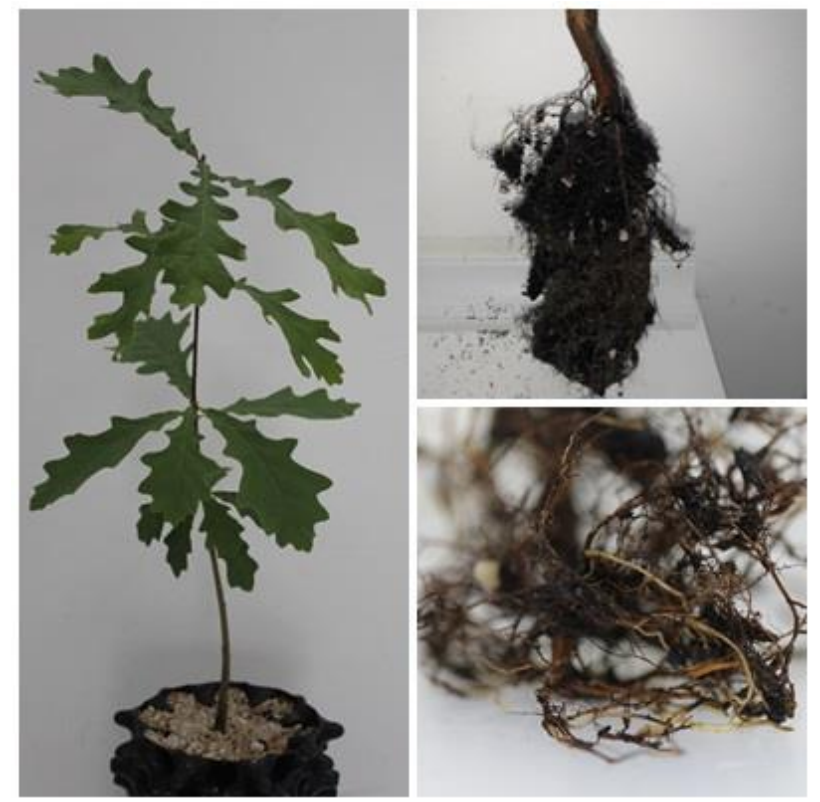

Figure 7. Shoot and roots development of 15-month-old oak seedlings inoculated with $T$. aestivum $\mathrm{Vittad}$

The truffle ascocarps that would be used in inoculation must be defined in an accurate manner both in taxonomic and in molecular terms. They must also be well-germinated and must have spores that may germinate. It must be cared that no other truffle ascocarps are mixed aside from those that would be inoculated. In addition, the height, stem length and diameter, and branching of the host plant must be in direct proportion with its age. The lignified stems and branches must be able to endure winter after plantation. The seedlings must be free from diseases and pests. Additionally, as Donnini et al. (2014) stated, the root structure of each sapling must be well-shaped and must consist of multiple side-roots.

According to the certification standards set by Fisher and Colinas (1996), T. aestivum was determined to be higher in amount in all oak types that were spore-inoculated to T. aestivum mycorrhiza, whose root rate was PT>0.50 $(33 \%)$. Contaminated (e.g. Sphaerosporella sp.) root rate was found to be $\mathrm{PC}<0.33$. (Contaminants $=$ no more than $25 \%$ of colonized root tips). This shows that the results of our study are fairly successful.

The best mycorrhizal development in oak trees after the 15 -month process was observed in $Q$. robur L., Q. coccifera L., $Q$. ilex L., respectively; and when the rating was made in terms of contamination from the lowest to the highest value, the rating was as $Q$. robur L., $Q$. ilex L., $Q$. coccifera $\mathrm{L}$. respectively. Despite being different species, they resulted in very similarly both in terms of mycorrhiza and contamination.

Being successful in truffle cultivation requires a longterm process. For this reason, the establishment of sowing areas starts with the selection of high-quality host plant. However, it will not suffice to select high-quality host, the other factors (mycorrhizal root rate, contamination rate, irrigation and care, etc.) are also important.

\section{Acknowledgements}

We would like to thank Niyazi Uluçoban for his assistance in growing oak seedlings.

\section{References}

Afyon, A., 1996. Isparta yöresinde belirlenen bazı makroskobik mantarlar. Turkish Journal of Botany, 20: 161-164.

Agerer, R., 1991. Characterization of ectomycorrhiza. In: Norris JR, Read DJ, Varma A (eds) Techniques for the study ofmycorrhiza Methods Microbiol, 23:25-73.

Arredondo-Ruiz F., García-Montero L. G., Díaz P., 2014. A review of research on Tuber aestivum (Summer truffle) focused on its culture. Forest systems (submitted).

Avis, P.G., McLaughlin, D.J., Dentinger, B.C., Reich, P.B., 2003. Long-term increase in nitrogen supply alters above- and below-ground ectomycorrhizal communities and increases the dominance of Russula spp. in a temperate oak savanna. New Phytol, 160:239-253.

Bencivenga, M., Di Massimo, G., 2000. Risultati produttivi di tartufaie coltivate di Tuber melanosporum Vitt. In Umbria. Micologia Italiana, 2:38-44.

Bonet, J. A., Oliach, D., Fischer, C. R., Olivera, A., De Aragón, J.M., Colinas, C., 2009. Cultivation Methods of the Black Truffle, the Most Profitable Mediterranean Non-Wood Forest Product; A State of the Art Review. EFI Proceedings. 1st Annual Meeting of the Modelling, Valuing and Managing Mediterranean Forest Ecosystems for Non-Timber Goods and Services, 26-27 October 2007, Palencia, Spain, 57-71.

Bonito, G., Trappe, J. M., Vilgalys, R., 2009. North American truffles in Tuberaceae: Molecular and morphological perspectives. Acta Botanica Yunnanica, 31(S16):39-51.

Bonito, G.M., Gryganskyi, A.P., Trappe, J.M., Vilgalys, R., 2010. A global meta-analysis of Tuber ITS rDNA sequences: Species diversity, host associations and long distance dispersal. Molecular Ecology, 19:4994-5008.

Callot, G.,1999. La Truffe, La Terre, la Vie. INRA, Paris, 210p.

Carbajo, P., 2000. Plantación de Arotz-Catesa. In: Jornadas de Truficultura. Viver, El Toro (Castellón).

Castellano, M.A., Turkoğlu, A., 2012. New records of truffle taxa in Tuber and Terfezia from Turkey. Turk J. Bot., 36:295-298.

Ceruti, A., Fontana, A., Nosenzo, C., 2003. Le specie del genere Tuber. Una revisione storica. Museo Regionale di Scienze Naturali, Torino.

Chevalier, G., Frochot, H., 1997a. La Truffe de Bourgogne. Editions Pétrarque, Levallois-Perret, ISBN: 978-2911730-01-6, 257p.

Chevalier, G., Frochot, H., 1997b. La Maîtrise de la culture de la truffe. Revue Forestière Française [Rev. For. Fr.], $49 \mathrm{~N}^{\mathrm{o}}$ special (Champignons et mycorrhizes en forêt), 49: 201-213.

Chevalier, G., Frochot, H., 2002. La Truffe de Bourgogne (Tuber uncinatum Chatin). Editions Petrarque, Levallois-Perret Cedex. ISBN-13: 978-2911730139, 257 p. 
Council Directive 1999/105/EC of 22 December 1999. On the marketing of forest reproductive material. Official Journal of the European Communities, 11:17-40.

Doğan, H. H., Öztürk C., 2006. Macrofungi and their distribution in Karaman Province. Turkish Journal of Botany, 30:193-207.

Donnini D, Benucci GMN, Bencivenga M, Baciarelli-Falini L., 2014. Quality assessment of truffle-inoculated seedlings in Italy: Proposing revised parameters for certification. For. Syst. 23(2):385-393. doi:10.5424/fs/2014232-05029.

Duell, G., 2012. The President's Report. National Conference of the Australian Truffle Growers Association. http://www.trufflegrowers.com.au/wpontent/uploads/2012/09/2012-Presidents-Report.pdf. (Accessed: 13 July 2013).

Escafre, A., Roussel, F., 2006. Rapport relatif au développement de la trufficulture française. Available in http://agriculture.gouv.fr/IMG/pdf/developpement truffi franc., (Accessed: 13 July 2013).

Fekete, A.O., Bagi, I., Conde, .IP., Iotti, M., Zambonelli, A., 2014. First report on the truffles of Azerbaijan. In: Re'sume's du deuxie'me symposium sur les champignons hypoge's du bassin mediterrane'en (HYPOGES2) et cinquie'me congre's Tuber aestivum/uncinatum du groupe scientifique europe'en (TAUESG5), Universite' Mohammed V, Rabat, 9-13 Apr,p19.

Fischer, C., Colinas, C., 1996. Methodology for the certification of Quercus ilex seedlings inoculated with Tuber melanosporum for commercial application. First International Conference in Mycorrhizae, August 4-9, Berkeley, California, USA.

Gardes,, M., Bruns, T., 1996. Community structure of ectomycorrhizal fungi in a Pinus muricata forest: aboveand below-ground views. Can. J. Bot 74:1572-1583.

Granetti., B., 1995. Caratteristiche morfologiche, biometriche e strutturali delle micorrize di Tuber di interesse economico. Micol Ital 2:101-117.

Gregori, G.L., 2013. Truffle and truffle cultivation in Italy: main aspects and news. 1st International Congress of Trufficulture Tuber March 5-8 Teruel (Spain).

Giorgio Marozzi G., Sánchez S., Benucci G.M. N., Bonito G., Falini L. B., Albertini E., Donnini D., 2016. Mycorrhization of pecan (Carya illinoinensis) with black truffles: Tuber melanosporum and Tuber brumale, Mycorrhiza, 27(3)1-7.

Gryndler, M., Hršelová, H., Soukupová, L., Streiblová, E., Valda, S., Borovička, J., Gryndlerová, H., Gažo, J., Miko, M., 2011. Detection of summer truffle (Tuber aestivum Vittad.) in ectomycorrhizae and in soil using specific primers. FEMS Microbiol Lett, 318:84-91.

Hall, I. R., Brown, G., Byars, J., 2001. The black truffle: Its history, uses and cultivation. Christchurch: New Zealand Institute for Corp \& Food Research Limited, Christchurch, New Zealand.

Hall, I. R., Yun, W., Amicucci, A., 2003. Cultivation of edible ectomycorrhizal mushrooms. Trends Biotechnology, 21:433-438.

Hall, I., Brown , G.T., Zambonelli, A., 2007. Taming the Truffle: The History, Lore and Science of the Ultimate Mushroom, Timber Press, Oregon, 304p.
Isiloglu, M., Oder, N., 1995. Malatya Yöresinin Makrofungusları. Turkish Journal of Botany. 19:321324.

Jeandroz. S., Murat, C.,Wang, Y., Bonfante, P., Le Tacon, F., 2008. Molecular phylogeny and historical biogeography of the genus Tuber, the "true truffles". Journal of Biogeography, 35:815-829.

Kaya, A., 2009. Macromycetes of Kahramanmaraş Province (Turkey). Mycotaxon, 108: 31-34.

Kovacs, G.M., Jakucs, E., 2006. Morphological and molecular comparison of white truffle ectomycorrhizae. Mycorrhiza, 16: 567-574.

Lange, C., 1994. Et år med Trøfler. Svampe, 29:1-5.

Lefevre, C. K., Hall, I.R., Mehlenbacher, S.A., 2001. Status of truffle cultivation: A global perspective. Acta Horticulturae, 556:513-520.

Marx D.H., 2001. Forest applycation of the ectomycorrhizal fungus Pisolithus tinctorius, The Prize: Ectomycorrhizal fungi, Lecture: Part I of II.

Mello, A., Murat, C., Bonfante, P., 2006. Truffles: Much more than a prized and local fungal delicacy. FEMS Microbiology Letters, 260:1-8.

Montecchi, A., Sarasini, M., 2000. Funghi ipogei d'Europa. Associazione Micologica Bresadola (eds), Reggio Emilia, Italy. Vicenza : Fondazione Centro Studi Micologici dell' A.M.B., 714p.

Morcillo, M., Moreno, B., Pulido, E., Sánchez, M., 2007. Manual de truficultura Andaluza. Ed. Gypaetus y Consejería de MedioAmbiente. Junta de Andalucía. p. 176.

Müller, W. R., Rauscher, T., Agerer, R., and Chevalier, G., 1996. Tuber aestivum Vitt.+ Corylus avellana L. Descr Ectomyc., 1:167-172.

Oder, N., 1988. Taxonomic investigations of important edible and poisonous mushrooms growing in the Konya center and some districts of Konya. Selçuk Üniversitesi Fen Edebiyat Fakültesi Dergisi, 8: 237-257.

Olivier, J. M., 2000. Progress in the cultivation of truffles. In: Proceedings of the 15th international congress on the science and cultivation of edible fungi, Maastricht, Netherlands, 15-19 May 2000, 937-942.

Reyna, S., Boronat, T., Palomar, E., 2000. Control de calidad en la planta micorrizada con Tuber melanosporum Vitt. producida por viveros comerciales. Montes, 61:17-24

Sen, I., Alli, H., Civelek, H.S., 2016. Checklist of Turkish truffles. Turkish Journal of Life Sciences, 1/2:103-109.

Serrada, R., 2008. Apuntes de Selvicultura. Madrid, Servicio de Publicaciones, EUIT Forestal: 452

Solak, M. H., Isiloglu, M., Kalmis, E., Alli, H., 2007. Macrofungi of Turkey, Checklist, Volume 1. Üniversiteliler Ofset, İzmir,254p.

Song, M.S., Cao, J.Z., Yao, Y.J., 2005. Occurrence of Tuber aestivum in China. Mycotaxon, 91:75-80.

Sourzat, P., 2001. Les limites des critères agronomiques dans l'analyse de terre en trufficulture. In: Actes du Ve Congrès International, Science et culture de la truffe, 46 march 1999, Aix-en-Provence, France., 5281-5286.

Stielow, B., Menzel, W., 2010. Complete nucleotide sequence of $\mathrm{TaV} 1$, a novel totivirus isolated from a black truffle ascocarp (Tuber aestivum Vittad.). Arch Virol, 155(12):2075-2078. 
Stobbe, U., Buntgen, U., Sprol,1 L., Tegel, W., Egli, S., Fink, S., 2012. Spatial distribution and ecological variation of re-discovered German truffle habitats. Fungal Ecology, 5: 591-599.

Stobbe, U., Egli, S., Tegel, W., Peter, M., Sproll, L., Büntgen, U., 2013. Potential and limitations of Burgundy truffle cultivation. Mini-Review Appl Microbiol Biotechnol, 97: 5215-5224.

Streiblová, E., Gryndlerová, H., Slavomir Valda, S., Gryndler, M., 2010. Tuber aestivum- hypogeous fungus neglected in the Czech Republic, A review. In Czech Mycology, vol. 61:163-173.

Trappe, J.M., Molina, R. L., Daniel, L., Cazares, E., Pilz, D., Smith, Jane, E., Castellano, M.A., Miller, S.L., 2009. Diversity, ecology, and conservation of truffle fungi in forests of the Pacific Northwest. Gen. Tech. Rep. PNW-GTR-772. Portland, OR: U.S. Department of Agriculture, Forest Service, Pacific Northwest Research Station, $194 \mathrm{p}$.

Turgeman,, T., Sitrit, Y., Dana, İO., Luzzati, Y., Bustan, A., Roth-Bejerano, N., Kagan-Zur, V., Masaphy, S., 2012. Introduced Tuber aestivum replacing introduced Tuber melanosporum: A case study. Agroforestry Systems, 84:337-343.

Turkoglu, A., Castellano, M. A., Trappe, J. M., Güngör, M. Y., 2015. Turkish truffles I: 18 new records for Turkey. Turkish Journal of Botany, 39:359-376.
Turkoglu, A., Castellano, M. A., 2014. New records of some Ascomycete truffle fungi from Turkey. Turkish Journal of Botany, 38:406-416.

Vittadini, C., 1831: Monographia Tuberacearum .Felicis Rusconi, Milano, Fransa, 88p.

Wedén, C., Danell, E. 1998. Tuber aestivum and other truffles in Sweden. Svensk Botanisk Tidskrift, 92:65-80. (In Swedish.)

Wedén, K., Danell, E., Camacho, F.J., Backlund, A. 2004. The population of the hypogeous fungus Tuber aestivum syn. T. uncinatum on the island of Gotland. Mycorrhiza, 14:19-23.

Yuanzhı, T., 2016, Method for cultivating wild truffles Google Patents, (CN105349435A).

Zambonelli, A., Salomoni, S., Pisi, A., 1993. Caratterizzazione anatomomorfologica delle micorrize di Tuber spp. su Quercus pubescens Willd. Micol Ital., 3:73-90.

Zambonelli, C., Chiavari, C., Benevelli, M., Fabio Coloretti, F., 2002. Effects of lactic acid bacteria autolysis on sensorial characteristics of fermented foods. Food Tech Biotechnol, 40: 347-351.

Zeppa, S., Sisti, D., Pierleoni, R., Potenza, L., Guescini, M., Vallorani, L., Stocchi, V., 2005. Tilia platyphyllos Scop.-Tuber brumale Vittad. vs. T. platyphyllos Scop. T. borchii Vittad. ectomycorrhizal systems: A comparison of structural and functional traits. Plant Physiol. Bioch. 43:709-716. 